\title{
奈良県の口腔領域腫瘍性疾患500例の病理学的検討
}

堀内敬介・青笹克之・上海道範昭*

桐田忠昭*・西岡博人*・杉村正伴

\section{Histological examination of 500 cases of oral tumorous lesions in Nara}

\author{
Keisuke Horiuchi - Katsuyuki Aozasa - Noriaki KamiKaido* \\ Tadaaki Kirita* * Hiroto NishiokA - Masahito Sugimura*
}

\begin{abstract}
Histology and brief clinical data in 500 oral tumor cases were reviewed and compared to those reported from Japanese and western institutes: they were admitted to the Department of Oral and Maxillofacial Surgery, Nara Medical University during 1981-1990.

The lesions were divided into 3 groups: non-odontogenic tumors (450 cases, 90\%), odontogenic tumors (24 cases, $4.8 \%$ ), and major salivary gland tumors (11 cases. 2. 2\%). Four hundred and fifty cases of non-odontogenic tumors were classified as non-neoplasia (46 $\%$ ), malignant $(28 \%)$ and benign $(14 \%)$ neoplasias, and dysplastic epithelium (11\%). Male to female ratio and mean age in cases with non-neoplastic lesions, benign tumors, dysplastic epithelium, and malignant tumors was $1: 1.9$ and 49 years, $1: 1.5$ and 39 years, 1.1 and 61 years, and $1.8: 1$ and 63 years, respectively. Tongue was the most frequent site for cancers $(32 \%$ of all cases) followed by floor of the mouth $(15.4 \%)$, gingiva $(14.5 \%)$, and maxillary sinus $(12.8 \%)$. Sites of epithelial dysplasia were tongue $(65 \%)$, cheek mucosa (18 $\%$ ), gingiva $(8 \%)$ and so on. The results of present study at Nara review of literature suggested that no remarkable differences were present in sex ratio, age, site of lesions, and histologic types among oral tumor cases in Japan and Western countries.
\end{abstract}

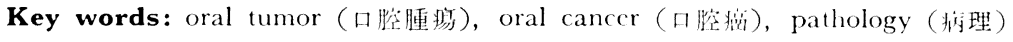

緒言

次患の発生には地域差，人们等があることはよく知ら れている。立た，同一地域において子経眝的に微誃与る と挨患の頻度に劣化がみられることがある。嗹境につい

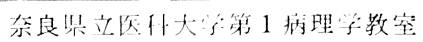

(主任：青篗克之教授）

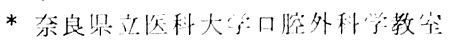
（主任：杉村正仁教授）

Department of Pathology, Nara Medical University (Chicf: Prof. Katsuyuki Aozasa)

* Department of Oral and Maxillofacial Surgery, Nara Medical University (Chief: Prof. Masahito Sugimura)

受付日：平成 2 年10月1日

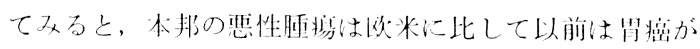
多く, 大腸癌, 肺癌, 乳嵒, 前立腺癌は少なかったが, 最近では滥癌が娍少し，肺癌，大蒘癌などが增加して欧 米型になりつつある゙また， ハワイの日本人移飞の一

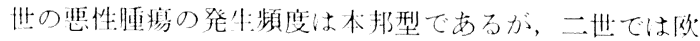

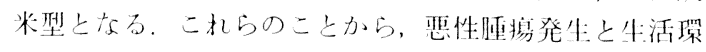

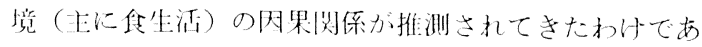

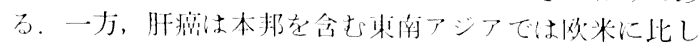
て発生率がかなり高いが，その原目として木邦，台湾な どでは HBsキャリアーの多いことがあげられている22. 政近では成人 T緗胞性りン八肧（ATL）は本那の他，力 リブ海諸国などのごく限られた地或にしか見い田され

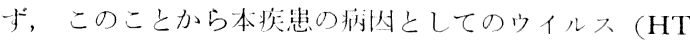
LV-1）の臣要性が明らかにされたのは周知のことであ

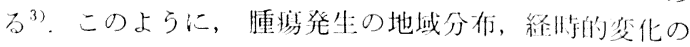

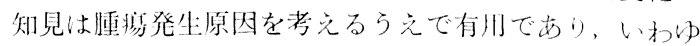


表 1 非牶原性腫㻛 450 例の組織学的分類

\begin{tabular}{|c|c|c|}
\hline 組織診断名 & $\begin{array}{c}\text { 例数 } 450 \text { 例中 } \\
(\%)\end{array}$ & $\begin{array}{c}\text { 疾患群中 } \\
(\%)\end{array}$ \\
\hline A）良性腫湯 & $65(14.4)$ & $(100.0)$ \\
\hline 乳頭腫 & $26(5.8)$ & $(40.0)$ \\
\hline 多形性腺腫 & $15(3.3)$ & $(23.1)$ \\
\hline 血管腫 & $11(2.4)$ & $(16.9)$ \\
\hline 周 畽 & $6(1.3)$ & $(9.2)$ \\
\hline 化骨性線稚腫 & $3(0.7)$ & $(4.6)$ \\
\hline リンハ、笛腫 & $1(0.2)$ & $(4.6)$ \\
\hline 脂肪腫 & $1(0.2)$ & $(1.5)$ \\
\hline 粘液腫 & $1(0.2)$ & $(1.5)$ \\
\hline 神程䩗腫 & $1(0.2)$ & $(1.5)$ \\
\hline B）覀性腫㿉 & $128(28.4)$ & $(100.0)$ \\
\hline a) 癌 腫 & & \\
\hline 扁平上皮猊 & $108(24.0)$ & $(84.4)$ \\
\hline 腺様䔶胞癌 & $5(1.1)$ & $(3.9)$ \\
\hline 腺 癌 & $1(0.2)$ & $(0.8)$ \\
\hline 粘表皮瘦 & $1(0.2)$ & $(0.8)$ \\
\hline 分類不能樆 & $1(0.2)$ & $(0.8)$ \\
\hline b) 肉腫 & & \\
\hline 悪性リンパ腫 & $3(0.7)$ & $(2.3)$ \\
\hline 骨肉腫 & $1(0.2)$ & $(0.8)$ \\
\hline 悪性楾維性組織球腫 & $1(0.2)$ & $(0.8)$ \\
\hline c）その他 & & \\
\hline 転移性腫痬 & $6(1.3)$ & $(4.9)$ \\
\hline 悪性黒色腫 & $1(0.2)$ & $(0.8)$ \\
\hline C）異型性疾患 & $51(11.3)$ & $(100.0)$ \\
\hline 白板症 & $49(10.9)$ & $(96.1)$ \\
\hline 犹 辋 & $2(0.4)$ & $(3.9)$ \\
\hline D）腫痬類似病変 & $206(45.8)$ & $(100.0)$ \\
\hline 上皮過形成症 & $2(0.4)$ & $(1.0)$ \\
\hline 楾維性過形成应 & $148(32.9)$ & $(71.8)$ \\
\hline 肉芽腫 & $36(8.0)$ & $(17.5)$ \\
\hline 動静脈瘦孔 & $20(4.5)$ & $(9.7)$ \\
\hline 合 計 & \multicolumn{2}{|l|}{$450(100.0)$} \\
\hline
\end{tabular}

る疫学的研究の重要性が認識されてきつつあるわけであ る.

ところで，口腔領域における腫晹性疾患の発症类態を 地域別，国別で比較検討した報告は乏しい。奈良県立医 科大学は奈良県の口腔内の腫瘍性疾患の大部分をカバー している。この奈良県は胃癌の多いことが知られている がその原因の1つに『茶がゆ』の椇取も考えられている. 本論文では，奈良県立医科大学の口腔外科開設以来の腫 堭性疾患を再検討し，その結果を本邦の他施設および欧 米からの報告と比較することにより，その異同を明らか
にすることを目的とした

\section{対象および方法}

奈良紧立医科大学口腔外科開設（1981 年10月）より 1990年 3 月までの 8 年 5 か月间に，口腔内腫溜形成を主

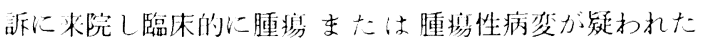
542 例中，病理学的に再顺討の可能てあった500例を対象 とした。採取標本は10\%ホルマリン国定徭，バラフィン 包埋し， 5〜6 $\mu \mathrm{m}$ で溥切してへマトキシリン・エオジン 染色を行い観察した。必要に応じて, PAS, アルシャ ン・ブルー,マロリ一染色を行った。各疾患は臨床所見 を参考にして, 組織学的に, 非歯原性腫湯, 歯原性腫 場, 大唾液腺腫瘍, その他に大别した。今回は非歯原性 腫瘍を中心に, 年柃, 性差, 各疾患の発生頻度, 組織型 などについて検討した。

結果

500例の性別は男性 234名, 女性 266名で, 男女比 1: 1.1でやや女性が多かった。平均年解は 51.6 歳であり, 年榆别では男女とも40，50，60歳代が多く，この3 世代 の合㖕で296例， $59.0 \%$ ，さらに70歳代を加えると，362 例, $72.1 \%$ の多数を占め, 50,60 歳代中心の分布を示 した（図１）。組織学的に大別すると非歯原性腫瘍が最 も多く450例 $(90 \%)$ ，飞の他林原性腫場 24 例 $(4.8 \%)$,

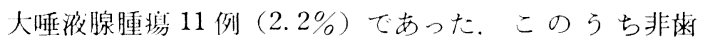
原性腫瘍を分類すると，新生物は193 例 (32.8\%) であ り，その内訳は良性腫晹65例 $(14.4 \%)$, 悪性腫惕128例 (28.4\%) である。萁型上皮は51例 $(11.3 \%)$, 腫煌類似 病変は206例 $(45.8 \%$ ) であった（表１）。ここに打る 異型上皮とは，白板症を含め，組䋐学的に種々の程度の 異型を伴う過形成を示与疾患群であり，また腫掦類似病 変とは，臨床的に義雪性線維腫やエプーリスなとの範鿬 にはいる線維性過形成症をはじめとした真の腫陽とは区 別すべき疾患群である。

良性腫瘍65例に拈计る男女比は 1：1.5 女女性に多く， また好発年粭が10～50歳代を中心に広範围に及んでおり (平均39歳, 图 2), 組䄉学的には乳頭腫26例 (40.0\%), 多形性腺腫15例 $(23.1 \%)$, 血管腫 11 例 $(16.9 \%)$ と, この3 疾患で $80 \%$ を占わた。このうち乳䫓腫についてみ ると, 男女比は 1:1.4 と女性に多く，20藏代と40～60 歳代にピークをもつ二猅性の分布を示した。好発部位て は口蓋に $38.5 \%$ と最も多く，ついで舌の $30.8 \%$, 畨肉, 煩粘膜のそれぞれ $11.5 \%$ であった。

一方，口腔原発覀性腫瘍122例に打ける男女比は1.8:1 と男性に多く，年㱓では50７0歲代に73.0\% が集中した 一峰性分布を示し, 平均年龄は63歳であった（図了）. 組織学的には扁平上皮癌が 108 例 $(84.4 \%)$ と大多数を 


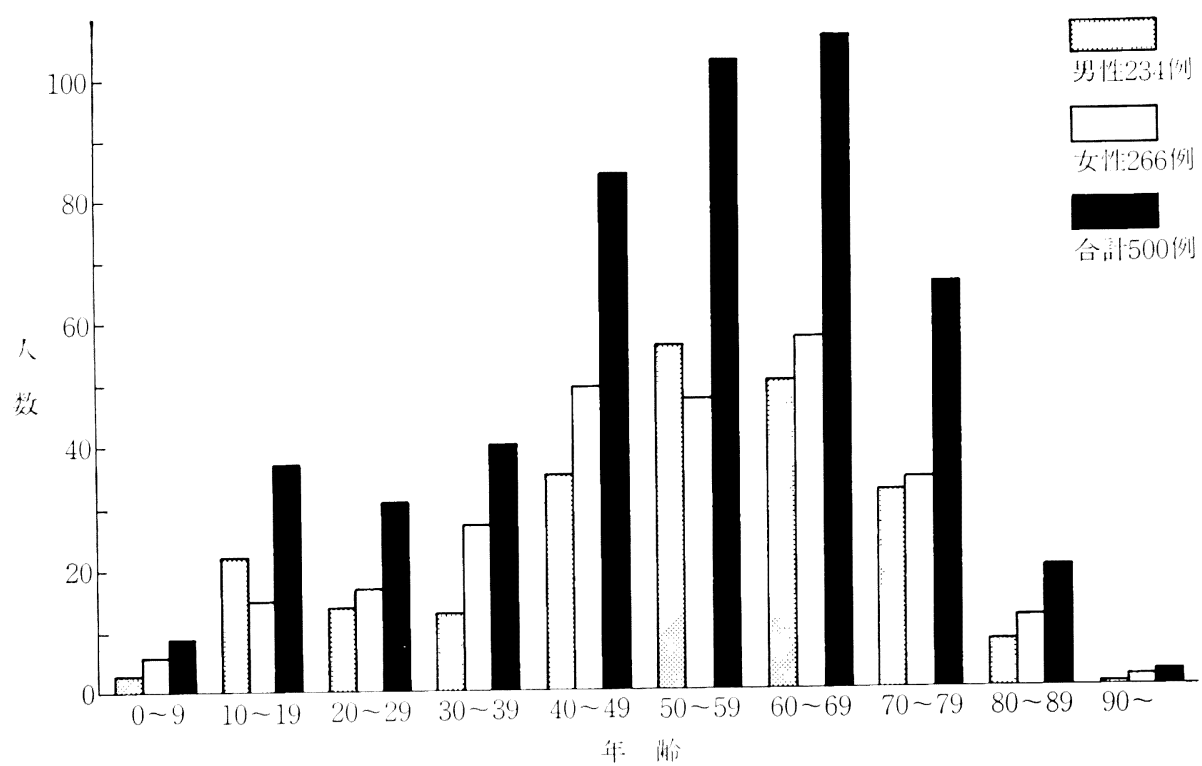

図 1 口腔領域腫增形成患者年㱓分有

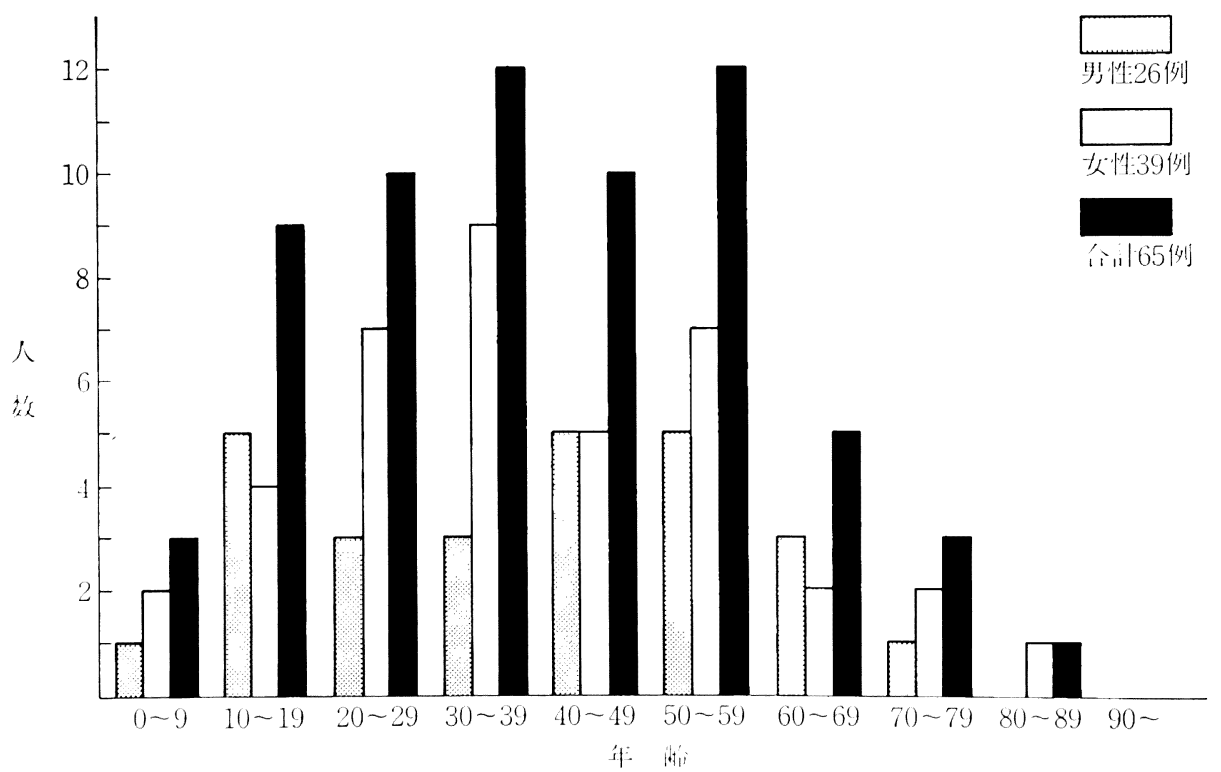

図 2 口腔領域良性腫愣年路分布

占め，その中でも高分化型が压倒的に多く，中分化型， 低分化型の順であった（図 4)。今们，上皮内癌，訧鳌 状癌も扁平上皮癌の冊型としてこの箅睭に含めた。ての 他, 腺様整胞癌 5 例, 腺癌, 粘表皮癌, 鑑别不能癌が各 1 例2られた。好発部位としては，舌に最も多く37 例

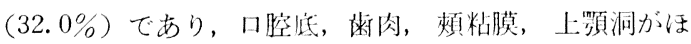

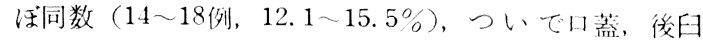
幽部，口唇の順であった（図 5 ）。肉腫は恶性りンハ腫 3 例, 會肉腫, 悪性線彩性組織球腫各 1 例の計 5 例, 3. $9 \%$ であった。

異型上皮としては日板症が49例（96.1\%）と大部分を 上め，その他訧贅状過形成症が 2 例のみであった。占板 


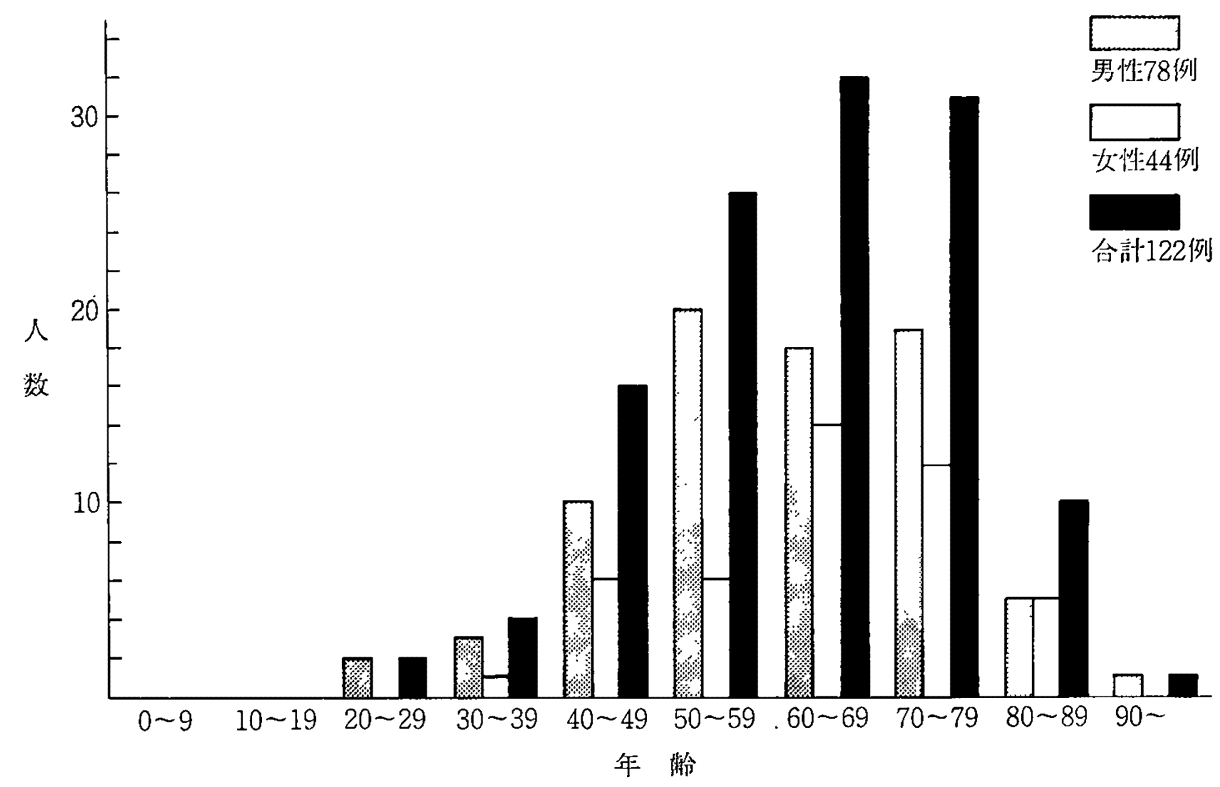

図 3 口腔領域原発悪性腫疼年齢分布

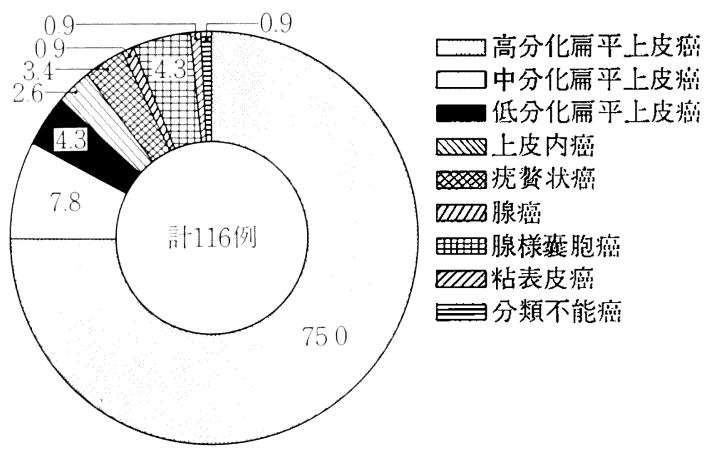

図 4 癌の組織学的分類

症について性差はみられず，年齢は 50〜60 歳代に 29 例 （59.0\%）と多く，平均年齡は61歳であった。好発部位 は舌に32例 (65.0\%) と多く，ついで類粘膜 9 例 (18.4 \%), 畨肉 4 例 $(8.2 \%)$ の順でその他の部位ではわずか であった，頭頸部尰隍取扱い規䄪 ${ }^{4)}$ に準じて異型度を検 索したところ，異型なしと軽度および中等度異型症例が ほぼ同数で多数を占め, 高度異型は 4 例のみであり40歳 代と50歳代の比較的若年層に分布しており，いずれる舌 に生じたものであった（図6，7）。これらのらち舌にお ける中等度異型の 1 例に癌化がみられ, 初診より 3 年 7 か月後に高分化扁平上皮癌として部断されている。

連瘍類似病変206例に拈いては, 男女比は 1:1.9 と女 性が 2 倍近くを占め, 年龄については 40〜60歳代に 127 人 $(61.7 \%)$ と多く, 平均年齡は 49.3 歳であった. 組織
学的には線維性過形成症が148例 $(71.8 \%)$ と最も多く, ついで化膿性肉芽腫 36 例 (17.5\%), 動静脈瘦孔 20 例 (9.7\%) であり，大部分が非上皮性疾患であった。

$$
\text { 考察 }
$$

本邦および欧米にお゙ける口腔腫瘍発生頻度を比較検討 する場合, 各施設間での臨床的, 病理学的分類の統一が 必要となってくる，しかし従来の報告では，疾患の発生 頻度を表現する場合の母数のとり方は各施設で必ずしも 同一ではないよらである，今回は他施設の報告から可能 な限り, 悪性腫瘍, 非歯原性良性腫瘍, 異型上皮, 腫瘍 類似病変のみを抜粋し, 比較検討を行った。なお, 線維 腫に関しては特記しているものを除き, 腫瘍類似病変の 範疇に含めた。

今回大別した覀性腫瘍, 良性腫瘍, 異型上皮, 腫瘍類 似病変の発生頻度についてみると, 当科および隣県の和 歌山医大 (坂本ら5)）の報告では大差がみられず，とも に, 腫瘍類似病変 $>$ 悪性腫痬 > 良性腫瘍>異型上皮であ った。一方, 阪大 (長谷川ら6) からの報告では悪性腫 瘍の頻度が高くなり, 良性腫瘍, 腫瘍類似病変の頻度は 低くなっている。これは病院の特性と思われ，すなわち 良性疾患の多くは関連病院にて処置され, 悪性腫瘍が比 較的多く紹介来院するためであろら。これに対し, 九歯 大 $\left(\right.$ 暒山ら ${ }^{7)}$ ) からの報告では腫瘳類似病変が少なく良 性腫瘍がやや多くなり，異なった分布を示している。 たヘルシンキ大学8 ${ }^{8}$ からの報告によると腫瘍類似病変の 


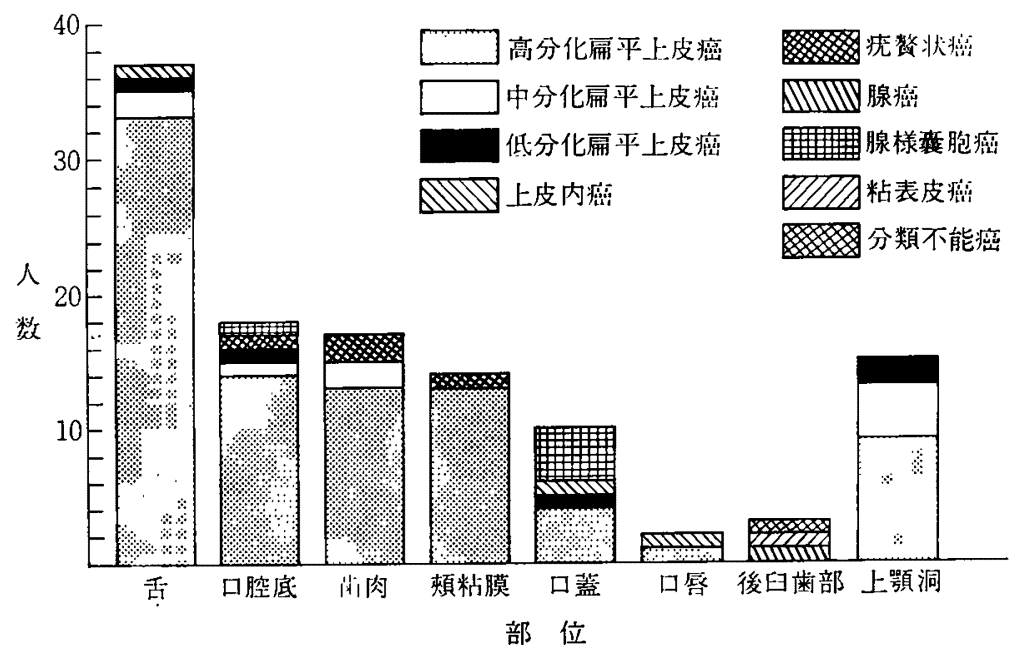

図 5 癌の組織・部位別分布

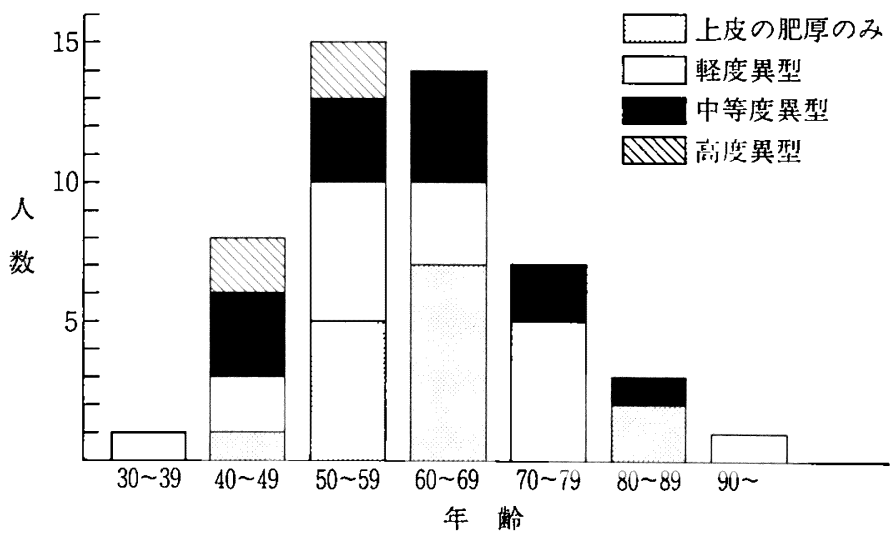

図 6 白板症の異型度と年踰分布

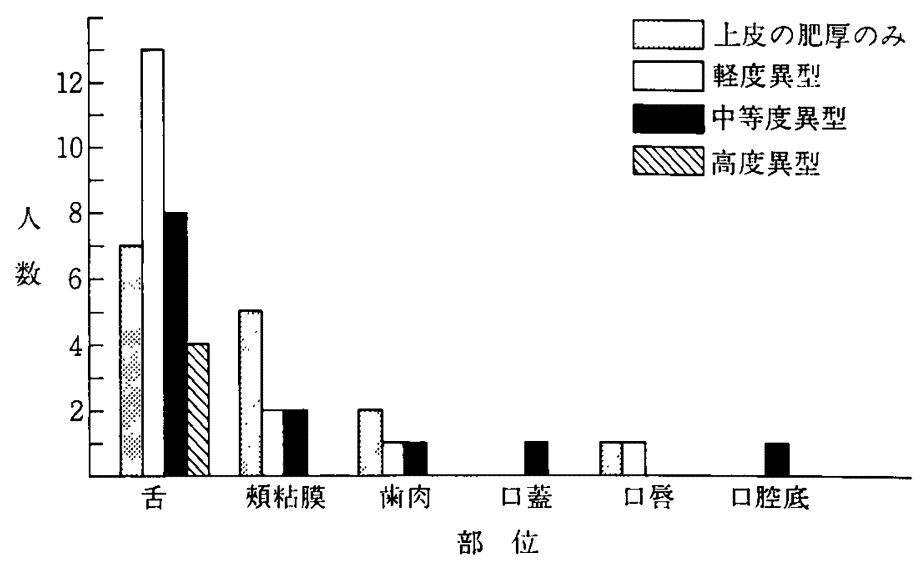

図 7 白板症の異型度と部位 
頻度がきわめて高く，4疾患群中の $84 \%$ を占めている。

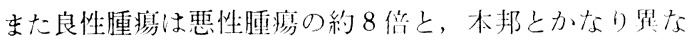
った分布を示している。この原风として，フィンラント

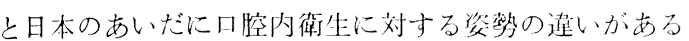
ことも考えられるが，口腔内悪性腫瘍の発生頻度につい ては人種的，地域的特性がみられるとする報告もある。

覀性腫瘦についてはすべての施設で存平上皮癌が大部 分を占めて扣り，全国統胡 ${ }^{9}$ や不邦行地 ${ }^{10 \sim 14) な ら ひ ゙ に 一 ~}$ ルシンキ8)では男性が多性の1.3〜2.5(倍の頻度で多く発 生している。一方, Krolls ${ }^{15)} ら$ (ワンントン) は, 口腔 癌14,253例中，93\%が男性であったと報告しており，本 邦よりさらに顕著な男性優位を示している。 また，92.6 \%が白人であり，人種による口腔癌の発生頻度の進いも 示唆している。好発年齢に関しては，へルシンキ8)では 60歳代，50歳代，70歳代の順に多く，この3 世代で74. 5 \%を占める。当科を含め本邦でも60藏代に最も多く, つ いで50歳代または70歳代と其通している。一j，ワシン トンでは60藏代，50践代，40藏代の順に多く，本邦に比 してやや若い傾向にあるが15)，ア大リカに打いて頻度の 高い口唇癌の好発年略が低下してきていることがその原 因之考えられている。好発部位については，全国統計 ${ }^{9}$ をはじめとして本邦では当科を含め, 多くの施設で舌に

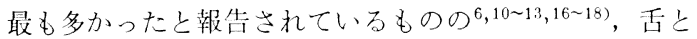
歯肉に同数 ${ }^{19)}$ ， あるいは齿肉が最好発部位であったと報 告している施設も少なからずみられ が本邦にお汁る口腔悪性腫瘍の好発部位であると考光ら れる。一力, 岩手医大 $\left(\right.$ 深沢ら $\left.{ }^{24)}\right)$ は上顎洞に最も多かっ たと報告しており，他施設と比して約 2 倍の頻度で観察

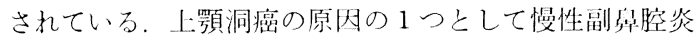
の関与があげられていることからも興味深い結果ではあ るが，その詳細については言及しておらず今後の報告が 望まれるところである。他国に捖いて，Ylipaavalniemis) は来肉 $(40 \%)>$ 舌 $(25 \%)>$ 頓粘膜 $(12 \%)$ の順に多か ったと報告しているが，同じフィンランドの Sainio ${ }^{25)}$ は約半数が舌にみられ，ついで頓粘膜であったとしてお り本邦の報告と類似性がうかがえる。一方，イギリスで は Lucas $^{26)}$ が舌 $(30 \%)>$ 口愿 $(25 \%)>$ 口腔底 $(15 \%)$, アメリカでは Krolls ら がが唇 $(38 \%)>$ 舌 $(22 \%)>$ 口腔底 $(17 \%)$ の順であったと報告しており，との地域 とも舌に多いことは事拣であるが，その他の好発部位に ついては地域により若干の造いがあるように思われる。 またアメリカでも黒人については口腔底 $(32 \%)>$ 占 $(19$ $\%)>$ 口蓋 $(18 \%)$ の順に多く， 口店はわずか1.9\%にす ぎなかったと報告されて打り 27)，口唇癌は黒人に少なく 白人の戸外労傎者に多いことがわかる。このことは発癌 要因としての人種と日光の重要性を㤝く示唆している. 口腔癌の発生頿度が非常に高いといわれているインドで は，煩粘膜 $(50 \%)>$ 舌 $(22 \%)$ 歯肉 $(12 \%)$ の順に多 かったと報告されており，乙の原因として chewing betel-nut p betel-leafの垍慣あるいは传生活の関与があ げられている28)，今回の当科における調㮐で，金国統 計抢よび本邦冬施設からの報告と比較して, 年略, 性 別，好発部位などに有意差がみられず，地域的な悪性腫 瘍発生の特性を見い出寸ことはできなかった。

良性腫痗については疫学的報告在している文献が少な く，多施設との比较が不问能であるが今盺調べた限りで は，性差，好発年脚，組織型ともに顕著な地域差が为ら れないようであり，男久比 1: 1.2 1. 6, 平均年略は 30 战代半ばから40歳代半ばであり，組織型は一部を除いて 乳頍腫が多く，ついで多形性腺腫または血管腫であっ た、ヘルンンキでは乳頡腫が約半数を占め本邦の報告よ りもやや多く，ついで血管腫であるが，第 3 位に化骨性 線維腫が多いのが特徵と思われる。腫廈類似病变の発生 頻度についての報告は少ないらえ，診断規準が異なるよ らであるため今四の比較検討は不可能であった。

以上，条良県に括ける口腔内非歯原性腫瘍の病理学的

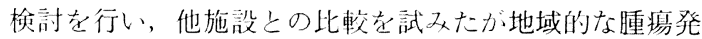
生頻度の特性はみられなかった。今後は臨㦿的, 病理学

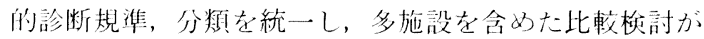
望まれる。

結 語

奈良県立医科大学口腔外科開設以来， 8 年 5 力月間に 口腔内腫瘍形成を主訴に来院し，臨床的に腫瘍を疑った 症例のらち病理学的に再㭘討可能であった 500 例につい て調査したところ, 奈良徂の腫痬性疾患の頻度，年粭分 布，好発部位，組織型などについて本邦および欧米他施 設からの報告と比較して明らかな違いはみられず，几腔

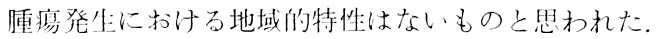

\section{引用 文 献}

1) Tominaga, S., Ogawa, H., et al.: Usefulness of correlation analysis in the epidemiology of stomach cancer. Nat Cancer Inst Monogr 62: 135-140 1982.

2) Coheu,C., Berson, S.D., et al.: Liver cell dysplasia. Association with hepatocellular carcinoma, cirrhosis and hepatitis B antigen carrier states. Cancer 44: 1671-1676 1979.

3) Hinuma, Y.: Association of retrovirus (ATLV) with adult $\mathrm{T}$ cell leukemia.: Review of serologic studies. Gann Monogr Cancer Res 28: 211-218 1982.

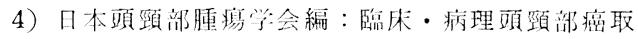
扱い挸䄪。金原出版，東京，1982，19-24面。

5）坂本忠萃，高木健次，他：口腔領域疾患の䜿床

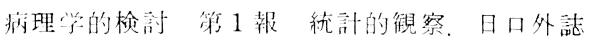
26: 1007-1010 1980 . 
6) 長谷川消, 高田和彰, 他：大阪大学㳡学部附 属病院中央检枯空病理部門に扣ける過去二ヶ乍 間の臨本病理材料415例の検舎.阪大蔯学誌 19 : 201-203 1974.

7) 梶山愁, 重住十成, 他：生检材料からみた最

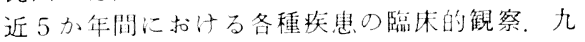
州附会誌 37：964-970 1983.

8) Ylipaavalniemi, P., Happonen, R.-P, et al.: Oral soft tissue pathology-An analysis of 6, 101 intraoral biopsies-. Proc Finn Dent Soc 83: 25-31 1987.

9)内田安信口腔腫源に関与る口腔外科全国統計 に上る疫学的研究。粕医兴誌 6: 17-31 1987 .

10）竹林俊明，石原吉孝，他：開設後 5 年間に扣 る当科覀性腫婸患者の臨木統計的観察(抄)。日 口外誌 33：2599 1987.

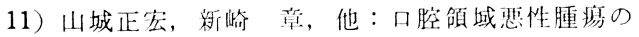

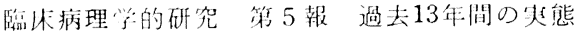
と地域的步察。日口外誌 34：287-292 1988.

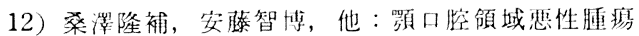
79例の臨床統計的観察。東女医大誌 57：152815351987.

13）堀みとりり，三吉瓜蚛，他・当教空20年間の口

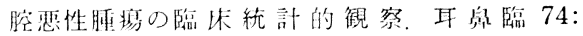
1025-1037 1981.

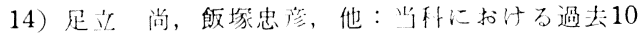

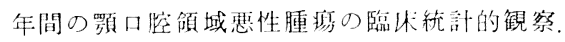
日口外誌 33：1442-1449 1987.

15) Krolls, S.O., Hoffman, S.: Squamous cell carcinoma of the oral soft tissues: a statistical analysis of 14, 253 cases by age, sex, and race of patients. JADA 92: 571-574 1976.

16)非出隆, 山浦明智, 他：口腔粘膜指の病因に 関する疫学調植(抄)。日口外誌 $33: 2732$ 1987.

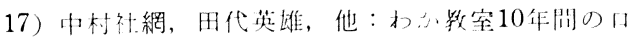

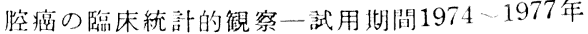
の TNM 分類にもとつてて一日日外誌 23： 533-539 1977.

18）堂原我美, 川平消秀, 他：わが教空に扣ける過 去10年間の顎口腔領域恐性腫瘍の臨林統計的観 察。日口外誌 25：548-558 1979.

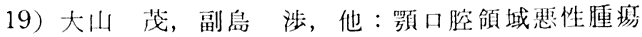
の臨床的研究一第 1 報口腔瘦（扁平上皮癌） の臨林統計的钼 察— 日口外誌 33：748-752 1987.

20）上野正：口腔癌の治療に闺する研究。口病誌 36: 4-19 1969.

21）化山孝光，竹中将純，他 . 当教室に扣ける過去 10年間の悪性腫瘳患者の臨床統計的観察。日口 外誌 29: 1738-1746 1983.

22) 赤領正之, 瀬山淳, 他：顎 - 口腔領域腎性腫

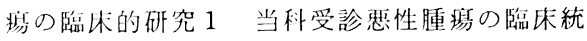
部的锶察。広大幽誌 11：101-105 1979.

23）小林操, 熱田滕雄, 他：最近10年間の口腔恵 件腫瘳患者の臨休統計的钼察(抄)。口科誌 30: 5441981.

24）深沢篗，阅山三䬦，他・当教室に扣ける過去

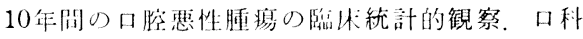
誌 30: 5441981 .

25) Sainio, P.: Intraoral squamous cell carcinoma in Finland. Proc Finn Dent Soc 73, Suppl. III : 471977.

26) Lucas, R.B.: Pathology of tumours of the oral tissues. 4th ed., ('hurchill Livingstone, 1984, p 124-131.

27) Leffall, L.D. Jr., White, J.E.: Cancer of the oral cavity in Negroes. Surg Gynecol Obstet 120: 70-73 1965.

28) Paymaster, J.C.: The problem of oral, oropharyngeal and hypopharyngeal carcinoma in India. Brit J Surg 44: 467-471 1957. 